\title{
What is the Accuracy of Nuclear Imaging in the Assessment of Periprosthetic Knee Infection? A Meta-analysis
}

\author{
Steven J. Verberne MD, Remko J. A. Sonnega MD, Olivier P. P. Temmerman MD, PhD, \\ Pieter G. Raijmakers MD, PhD
}

Received: 13 September 2016/Accepted: 19 December 2016/Published online: 3 January 2017

(c) The Author(s) 2016. This article is published with open access at Springerlink.com

\begin{abstract}
Background In the assessment of possible periprosthetic knee infection, various imaging modalities are used without consensus regarding the most accurate technique.

Questions/Purposes To perform a meta-analysis to compare the accuracy of various applied imaging modalities in the assessment of periprosthetic knee infection.

Methods A systematic review and meta-analysis was conducted with a comprehensive search of MEDLINE and Embase $^{\mathbb{R}}$ in accordance with the PRISMA and Quality Assessment of Diagnostic Accuracy Studies (QUADAS-2)
\end{abstract}

Each author certifies that he, or a member of his immediate family, has no funding or commercial associations (eg, consultancies, stock ownership, equity interest, patent/licensing arrangements, etc) that might pose a conflict of interest in connection with the submitted article.

All ICMJE Conflict of Interest Forms for authors and Clinical Orthopaedics and Related Research ${ }^{\circledR}$ editors and board members are on file with the publication and can be viewed on request.

This work was performed at Centre for Orthopaedic Research Alkmaar, NWZ, Alkmaar, The Netherlands.

Electronic supplementary material The online version of this article (doi:10.1007/s11999-016-5218-0) contains supplementary material, which is available to authorized users.

S. J. Verberne $(\bowtie)$, R. J. A. Sonnega, O. P. P. Temmerman Department of Orthopaedics, Noordwest Ziekenhuisgroep, Wilhelminalaan 12, 1815 JD Alkmaar, NWZ, The Netherlands e-mail: stevenverberne@hotmail.com

S. J. Verberne, R. J. A. Sonnega, O. P. P. Temmerman The Centre for Orthopaedic Research Alkmaar (CORAL), Noordwest Ziekenhuisgroep, Alkmaar, The Netherlands

P. G. Raijmakers

Department of Radiology \& Nuclear Medicine, VU University Medical Centre, Amsterdam, The Netherlands recommendations to identify clinical studies in which periprosthetic knee infection was investigated with different imaging modalities. The sensitivity and specificity of each imaging technique were determined and compared with the results of microbiologic and histologic analyses, intraoperative findings, and clinical followup of more than 6 months. A total of 23 studies, published between 1990 and 2015, were included for meta-analysis, representing 1027 diagnostic images of symptomatic knee prostheses. Quality of the included studies showed low concerns regarding external validity, whereas internal validity indicated more concerns regarding the risk of bias. The most important concerns were found in the lack of uniform criteria for the diagnosis of a periprosthetic infection and the flow and timing of the included studies. Differences among techniques were tested at a probability less than 0.05 level. Where there was slight overlap of confidence intervals for two means, it is possible for the point estimates to be statistically different from one another at a probability less than 0.05 . The z-test was used to statistically analyze differences in these situations.

Results Bone scintigraphy was less specific than all other modalities tested $(56 \%$; 95\% CI, 0.47-0.64; p < 0.001), and leukocyte scintigraphy (77\%; 95\% CI, 0.69-0.85) was less specific than antigranulocyte scintigraphy $(95 \% ; 95 \%$ CI, 0.88-0.98; $\mathrm{p}<0.001$ ) or combined leukocyte and bone marrow scintigraphy $(93 \% ; \quad 95 \%$ CI, 0.86-0.97; $\mathrm{p}<0.001)$. Fluorodeoxyglucose positron emission tomography (FDG-PET) $(84 \%$; 95\% CI, 0.76-0.90) was more specific than bone scintigraphy $(56 \%$; $95 \%$ CI, $0.47-$ $0.64 ; \mathrm{p}<0.001$ ), and less specific than antigranulocyte scintigraphy $(95 \% ; 95 \% \mathrm{CI}, 0.88-0.98 ; \mathrm{p}=0.02)$ and combined leukocyte and bone marrow scintigraphy (93\%; 95\% CI, 0.86-0.97; p < 0.001). Leukocyte scintigraphy (88\%; 95\% CI, 0.81-0.93; $\mathrm{p}=0.01)$ and antigranulocyte 
scintigraphy $(90 \% ; 95 \% \mathrm{CI}, 0.78-0.96 ; \mathrm{p}=0.02)$ were more sensitive than FGD-PET (70\%; 95\% CI, 0.56-0.81). However, because of broad overlapping of confidence intervals, no differences in sensitivity were observed among the other modalities, including combined bone scintigraphy $(93 \%$; 95\% CI, 0.85-0.98) or combined leukocyte and bone marrow scintigraphy $(80 \%$; $95 \% \mathrm{CI}$, $0.66-0.91 ; \mathrm{p}>0.05$ for all paired comparisons).

Conclusions Based on current evidence, antigranulocyte scintigraphy and combined leukocyte and bone marrow scintigraphy appear to be highly specific imaging modalities in confirming periprosthetic knee infection. Bone scintigraphy was a highly sensitive imaging technique but lacks the specificity needed to differentiate among various conditions that cause painful knee prostheses. FDG-PET may not be the preferred imaging modality because it is more expensive and not more effective in confirming periprosthetic knee infection.

Level of Evidence Level III, diagnostic study.

\section{Introduction}

After primary TKA, as many as $2 \%$ of patients have prosthetic joint infection (PJI) develop; this risk is as great as 5\% after revision surgery $[3,26]$ Accurate diagnosis of periprosthetic infection remains a clinical challenge, particularly in subacute or chronic infections. The evaluation of suspected PJI is characterized by a multimodality workup including microbiologic, laboratory (elevated erythrocyte sedimentation rate, C-reactive protein [CRP]), synovial marker, and histologic tests [35, 57]. Recently, promising results have been reported regarding synovial biomarkers tests, including the alpha defensin immunoassay and synovial fluid CRP tests [5, 54]. However, these test are not yet widely available and their utility has been confirmed in only a few studies [54]. In addition to these diagnostic tests, various imaging techniques including radiographs, ultrasound, CT, MRI, bone, leukocyte, bone marrow, or antigranulocyte scintigraphy, and positron emission tomography (PET) can be used in the assessment of suspected periprosthetic knee infection $[10,11,29,31,57]$, especially in the case of a challenging diagnosis of a chronic or low-grade infection [45-48].

A delay in diagnosing and treating a periprosthetic knee infection can have a critical effect on loosening or maintaining the prosthesis and joint function. Timely identification of a periprosthetic infection is essential to allow initiation of appropriate medical and surgical therapies [49] in which various imaging modalities can contribute when other tests are inconclusive. However, inconsistent diagnostic accuracies across studies investigating periprosthetic knee infection have been published $[10,11,22]$. Consequently, the choice of the most accurate imaging technique remains controversial $[11,31]$. To our knowledge, there has been no meta-analysis comparing the most commonly used imaging modalities to evaluate TKA PJI.

The aim of this systematic review and meta-analysis was to compare the diagnostic accuracy of different imaging modalities used for diagnosing periprosthetic knee infection.

\section{Materials and Methods}

\section{Search Criteria and Strategy}

The imaging modalities that were reviewed for the assessment of periprosthetic knee infection were radiography, ultrasound, CT, MRI, scintigraphy (including bone, antigranulocyte, leukocyte, and bone marrow scintigraphy), and PET.

In June 2015 a computer-aided search of the PubMed and Embase ${ }^{\mathbb{R}}$ databases was conducted and updated in January 2016 (Appendix 1. Supplemental material is available with the online version of $C O R R^{\circledR}$ ). The search was restricted regarding primary studies that were written in English. For each database, a specific search strategy was developed (Fig. 1) with a medical informatics specialist. Reference lists of the identified studies and relevant reviews were hand-searched for supplementary eligible studies. The search was performed according to the PRISMA Statement (Appendix 2. Supplemental material is available with the online version of $C O R R^{\circledR}$ ) [24].

\section{Study Selection}

The following inclusion criteria were used for eligible studies: (1) radiography, ultrasound, CT, MRI, scintigraphy, and PET were used to identify suspected periprosthetic knee infections; (2) a valid reference standard of positive intraoperative culture whether combined with histopathologic evidence regarding acute inflammation of the periprosthetic tissue of surgical débridement or prosthesis removal and/or the presence of a sinus tract that communicates with the prosthesis $[8,13,29]$ and/or a clinical followup of at least 6 months; and (3) adequate details to reconstruct a two-by-two contingency table to determine the results of the index tests. Exclusion criteria were (1) animal studies; (2) non-English studies; (3) studies that did not differentiate between various joint replacements; and (4) case reports. Potential overlap of patient 


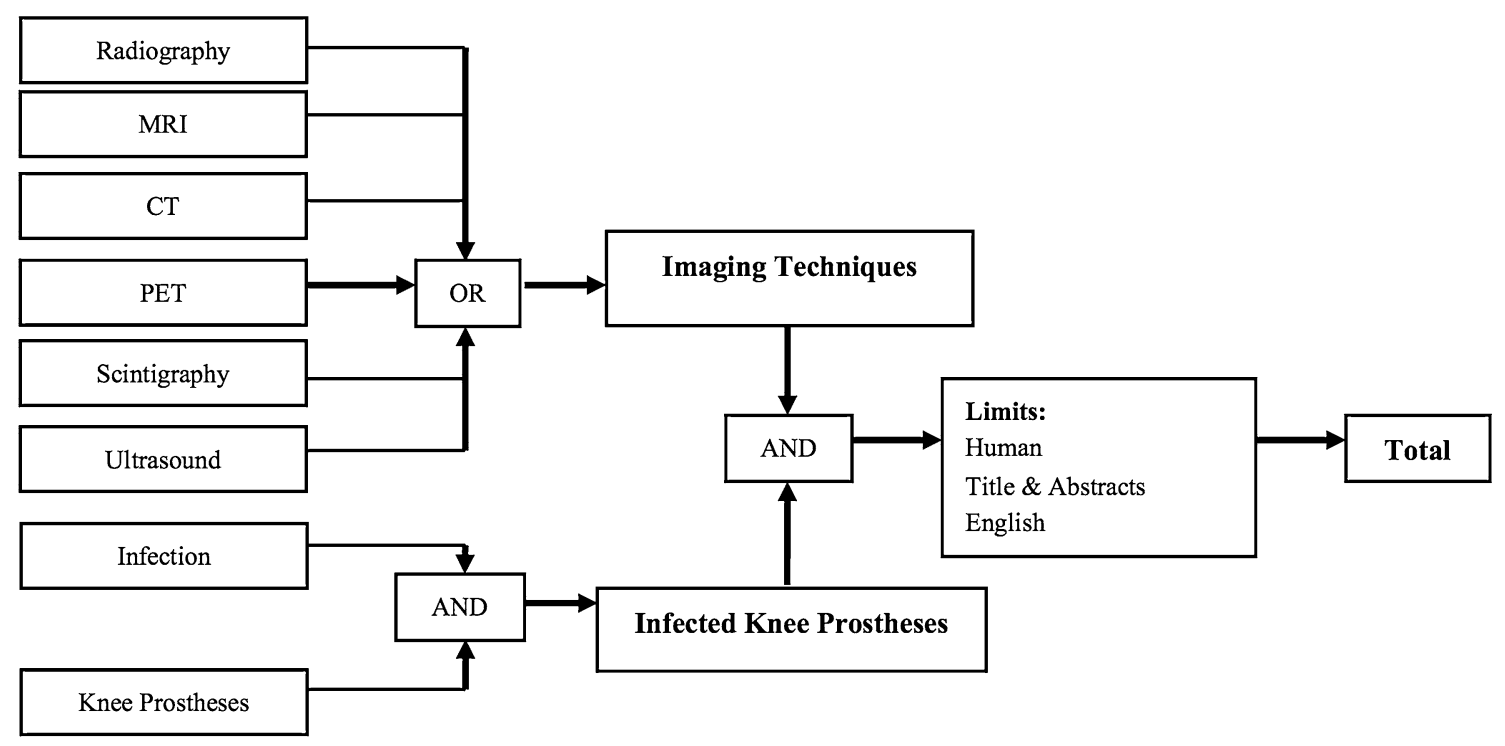

Fig. 1 The flowchart shows the search strategy we used for this study.

populations was assessed when more than one study was selected by the same author or institution by comparing the patient demographics. The study with the largest number of patients was selected when an overlap of patient populations between studies was observed.

The titles were screened for eligibility by one reviewer (SJV) and then processed for abstract assessment. The titles and abstracts were independently screened and assessed in an unblinded standardized manner for eligibility by two reviewers (SJV, RJAS). The final decision regarding inclusion was based on the full article. Disagreement in the evaluation of three studies was resolved with consensus by a third reviewer (OPPT). A priori, no differentiation was made for the type of knee implant, the interpretation criteria used for the index test, or the time between surgery and imaging.

\section{Studies Included}

The search strategy identified 3708 studies from MEDLINE and 2864 studies from Embase ${ }^{\circledR}$. The source population was formed by the total of 6572 studies (including duplicates). In 1933 studies, overlap was found between the retrieved studies from Embase ${ }^{\mathbb{R}}$ and MEDLINE. Of the initial 6572 studies, 6433 were excluded after analyzing the information provided in the title and abstract. The full articles of the remaining 139 studies were reviewed for eligibility (Appendix 2. Supplemental material is available with the online version of $C O R R^{\circledR}$ ). No other studies were extracted from the reference list of these studies. A total of 116 studies were excluded because the study was not a clinical diagnostic study (32\%), did not describe periprosthetic knee infection (12\%), was not written in English (17\%), did not specify the definition of positivity regarding the index test or applied an insufficient reference standard for periprosthetic knee infection (7\%), did not differentiate regarding different prosthetic joint replacements $(15 \%)$, did not provide data to reproduce twoby-two contingency tables (16\%), or the study revealed a potential overlap of the patient population $(1 \%)$. Eventually, 23 studies were included in this review.

\section{Description of Study Characteristics}

Of the 23 studies included for meta-analysis, six used bone scintigraphy [12, 20, 27, 34, 40, 50], four used bone leukocyte scintigraphy $[20,34,41,50]$, six used leukocyte scintigraphy [18, 28, 34, 37, 38, 50], seven used leukocyte bone marrow scintigraphy $[2,7,9,16,17,21,34]$, five used antigranulocyte scintigraphy $[14,15,40,44,52]$, and five used fluorodeoxyglucose (FDG)-PET [2, 21, 23, 50, 56]. Altogether, a total of 1027 diagnostic images, 404 (39\%) with and $623(61 \%)$ without periprosthetic knee infection, were evaluated in 1502 patients with 763 knee prostheses, of which 288 (38\%) were infected (Table 1). Of the studies not included for meta-analysis, two studies used ciprofloxacin scintigraphy and one used IgG scintigraphy. No studies were included that used radiographs, ultrasound, CT, MRI, or combined bone and gallium scintigraphy. The two reviewers (SJV, RJAS) independently extracted relevant data of the included studies, which included demographic, implant, and index test characteristics 
Table 1. Characteristics of the included studies

\begin{tabular}{|c|c|c|c|c|c|c|c|c|c|}
\hline Study & Year & Design $^{*}$ & $\begin{array}{l}\text { Number } \\
\text { of } \\
\text { patients }\end{array}$ & $\begin{array}{l}\text { Patients } \\
\text { demographics } \\
\text { (male/ } \\
\text { female) }\end{array}$ & $\begin{array}{l}\text { Age } \\
\text { (range) }\end{array}$ & $\begin{array}{l}\text { Age } \\
\text { (mean) }\end{array}$ & $\begin{array}{l}\text { Number of } \\
\text { prostheses }\end{array}$ & $\begin{array}{l}\text { Reference } \\
\text { standard }\end{array}$ & $\begin{array}{l}\text { Number of } \\
\text { hip } \\
\text { prostheses } \\
\text { (total/ } \\
\text { infected) }\end{array}$ \\
\hline Rand \& Brown [38] & 1990 & Retrospective & 38 & $16 / 22$ & $26-86$ & 65.0 & 38 knee & $\mathrm{M}, \mathrm{H}, \mathrm{IOF}$ & $38 / 18$ \\
\hline Palestro et al.[34] & 1991 & Retrospective & 28 & $7 / 21$ & $23-85$ & 65.0 & 32 knee & M, IOF, CFU & $32 / 9$ \\
\hline Ooi et al. [28] & 1993 & NR & 19 & $11 / 8$ & $25-84$ & NR & 6 knee & $\mathrm{M}, \mathrm{H}, \mathrm{IOF}, \mathrm{CFU}$ & $6 / 3$ \\
\hline Nijhof et al. [27] & 1997 & NR & 226 & $108 / 118$ & $5-90$ & 54.0 & 87 hip, 17 knee & $\mathrm{M}, \mathrm{IOF}, \mathrm{CFU}$ & $17 / 3$ \\
\hline Scher et al. [41] & 2000 & NR & 143 & NR & $26-87$ & 61.0 & 91 hip, 40 knee & $\mathrm{M}, \mathrm{H}, \mathrm{IOF}$ & $40 / 14$ \\
\hline van Acker et al. [50] & 2001 & Prospective & 21 & $8 / 13$ & $33-78$ & 66.0 & 22 knee & $\mathrm{M}, \mathrm{CFU}$ & $22 / 6$ \\
\hline Joseph et al. [16] & 2001 & Retrospective & 58 & $18 / 40$ & $27-82$ & 60.0 & 36 hip, 22 knee & $\mathrm{M}, \mathrm{H}, \mathrm{IOF}$ & $22 / 6$ \\
\hline Larikka et al. [20] & 2001 & Prospective & 28 & $4 / 24$ & $47-82$ & 75.0 & 30 knee & M, IOF & $30 / 8$ \\
\hline Zhuang et al. [56] & 2001 & NR & 62 & NR & $27-81$ & NR & 38 hip, 36 knee & $\mathrm{M}, \mathrm{IOF}, \mathrm{A}, \mathrm{CFU}$ & $36 / 11$ \\
\hline Ivancevic et al. [14] & 2002 & Retrospective & 30 & $13 / 17$ & $30-85$ & $\begin{array}{c}\text { Median } \\
\quad 62.0\end{array}$ & 21 hip, 6 knee & $\mathrm{M}, \mathrm{H}$ & $6 / 2$ \\
\hline El Espera et al.[7] & 2004 & NR & 60 & NR & NR & NR & 45 hip, 28 knee & $\mathrm{M}, \mathrm{IOF}, \mathrm{A}$ & $28 / 7$ \\
\hline Love et al. [21] & 2004 & NR & 59 & $22 / 37$ & $35-89$ & NR & 40 hip, 19 knee & $\mathrm{M}, \mathrm{H}, \mathrm{IOF}$ & $19 / 11$ \\
\hline Pelosi et al. [37] & 2004 & Retrospective & 78 & $36 / 42$ & $30-87$ & 70.0 & 47 hip, 40 knee & $\mathrm{M}, \mathrm{IOF}, \mathrm{CFU}$ & $40 / 25$ \\
\hline $\begin{array}{l}\text { von Rothenburg et al. } \\
\text { [52] }\end{array}$ & 2004 & Retrospective & 38 & $9 / 29$ & $45-81$ & 71.0 & 26 hip, 12 knee & M, IOF, A, L & $12 / 4$ \\
\hline $\begin{array}{l}\text { Iyengar \& Vinjamuri } \\
{[15]}\end{array}$ & 2005 & Retrospective & 38 & $18 / 20$ & $54-89$ & NR & $\begin{array}{l}17 \text { hip, } 13 \text { knee, } \\
8 \text { other }\end{array}$ & $\mathrm{M}, \mathrm{IOF}, \mathrm{A}, \mathrm{I}, \mathrm{CFU}$ & $13 / 2$ \\
\hline Stumpe et al. [44] & 2006 & Prospective & 28 & $13 / 15$ & $50-86$ & $67.0 / 59.0$ & 28 knee & $\mathrm{M}, \mathrm{CFU}$ & $28 / 3$ \\
\hline Rubello et al. [40] & 2008 & Prospective & 78 & $27 / 51$ & $49-81$ & 5.0 & 78 knee & $\mathrm{M}, \mathrm{CFU}$ & $78 / 41$ \\
\hline Mayer-Wagner et al. [23] & 2010 & NR & 32 & $13 / 19$ & $45-90$ & NR & 30 hip, 44 knee & M & $16 / 7$ \\
\hline Fuster et al. [9] & 2011 & Prospective & 40 & $14 / 26$ & NR & 66.0 & $\begin{array}{c}21 \text { hip, } 16 \text { knee, } \\
3 \text { shoulder }\end{array}$ & $\mathrm{M}, \mathrm{IOF}, \mathrm{CFU}$ & $16 / 6$ \\
\hline Jung et al. [17] & 2012 & Prospective & 11 & $2 / 9$ & NR & 72.0 & 11 knee & $\mathrm{M}, \mathrm{H}, \mathrm{IOF}, \mathrm{CFU}$ & $11 / 5$ \\
\hline Basu et al. [2] & 2014 & Prospective & 87 & $35 / 52$ & $32-83$ & 57.0 & $\begin{array}{l}134 \text { hip, } 87 \\
\text { knee }\end{array}$ & $\mathrm{M}, \mathrm{H}, \mathrm{IOF}$ & $87 / 19$ \\
\hline Kim et al. [18] & 2014 & Retrospective & 164 & $53 / 111$ & $17-82$ & 65.0 & 71 hip, 93 knee & $\begin{array}{l}\mathrm{M}, \mathrm{H}, \mathrm{IOF}, \mathrm{CFU}, \\
\mathrm{A}\end{array}$ & $93 / 63$ \\
\hline Granados et al. [12] & 2015 & Prospective & 120 & $50 / 70$ & NR & 71.0 & 63 hip, 57 knee & $\mathrm{M}, \mathrm{CFU}$ & $57 / 8$ \\
\hline
\end{tabular}

* Explicit notation in study; $\mathrm{M}=$ microbiology; $\mathrm{H}=$ histology; $\mathrm{IOF}=$ intraoperative findings; $\mathrm{A}=$ aspiration; $\mathrm{L}=$ laboratory (erythrocyte sedimentation rate, C-reactive protein); $\mathrm{I}=$ imaging; $\mathrm{CFU}=$ clinical followup at least 6 months; $\mathrm{NR}=$ not recorded.

(Table 2). Imaging procedures, image interpretation, and the effects of time after surgery as determined by the publication data (to form subgroups when possible) were analyzed in detail, such as data regarding diagnostic performance indices (eg, sensitivity and specificity).

\section{Methodologic Quality Assessment}

The criteria list of the Quality Assessment of Diagnostic Accuracy Studies (QUADAS-2) for evaluating internal and external validity of diagnostic studies recommended by the Cochrane Screening and Diagnostic Tests Methods Group (http://methods.cochrane.org/sdt/handbook-dta-reviews) was used for grading the methodologic quality of the selected studies [53]. Evaluation was performed by two reviewers (SJV, RJAS) independently. Internal and external criteria were used for determination of the methodologic limitations, respectively, for descriptive purposes. Studies, however, were not excluded from the systematic review on the basis of quality.

The external validity showed low concerns regarding applicability in more than $85 \%$ of the included studies (Fig. 2). The internal validity of the included studies showed more concerns regarding the risk of bias. Approximately $50 \%$ of the included studies did not provide sufficient information regarding patient selection, reference standard, and flow and timing. 
Table 2. Characteristics of the reference test(s) and implants

\begin{tabular}{|c|c|c|c|c|c|}
\hline Study & $\begin{array}{l}\text { Hip prostheses } \\
\text { (primary/ } \\
\text { revision) }\end{array}$ & $\begin{array}{l}\text { Cemented/ } \\
\text { uncemented }\end{array}$ & Age of knee prostheses & $\begin{array}{l}\text { Imaging: minimal time } \\
\text { after surgery }\end{array}$ & $\begin{array}{l}\text { Minimal } \\
\text { followup } \\
\text { (months) }\end{array}$ \\
\hline Rand \& Brown [38] & P30, R8 & $\begin{array}{l}\mathrm{C} 34, \mathrm{U} 2 \\
\mathrm{H} 2\end{array}$ & Mean 27 months (1-100 months) & $>1$ month & NR \\
\hline Palestro et al. [34] & NR & NR & Mean 6 years ( 3 weeks to 13 years) & $>3$ weeks & $>6$ \\
\hline Ooi et al. [28] & NR & NR & $3-18$ months & $>3$ months & NR \\
\hline Nijhof et al. [27] & NR & C16, U1 & 4.5 years ( 6 weeks to 21 years) & $>6$ weeks & $>12$ \\
\hline Scher et al. [41] & $\mathrm{P} 40$ & NR & NR & $\begin{array}{l}\text { Mean } 71 \text { months (median } \\
47 \text { months) }\end{array}$ & NR \\
\hline van Acker et al. [50] & P16, R5 & C12, U9 & $\begin{array}{l}\text { Mean } 35.0 \text { months ( } 7 \text { months to } \\
9 \text { years) }\end{array}$ & $>7$ months & $>6$ \\
\hline Joseph et al. [16] & NR & NR & NR & NR & NR \\
\hline Larikka et al. [20] & NR & NR & $\begin{array}{l}\text { Median } 4 \text { years } 8 \text { months } \\
\text { ( } 1 \text { month to } 16 \text { years })\end{array}$ & NR & $>12$ \\
\hline Zhuang et al. [56] & NR & NR & 3 months to 8 years & $>3$ months & $>12$ \\
\hline Ivancevic et al. [14] & NR & NR & NR & Median 13 months (2-80 months) & $>6$ \\
\hline El Espera et al. [7] & NR & NR & Mean 5.4 years & NR & $>3$ \\
\hline Love et al. [21] & $\mathrm{P} 17, \mathrm{R} 2$ & C18, U1 & 1 week to 19 years & $>1$ week & NR \\
\hline Pelosi et al. [37] & NR & NR & NR & NR & $>12$ \\
\hline $\begin{array}{l}\text { von Rothenburg et al. } \\
\text { [52] }\end{array}$ & NR & C6, U6 & 2 months to 10 years & $>2$ months & NR \\
\hline $\begin{array}{l}\text { Iyengar \& Vinjamuri } \\
{[15]}\end{array}$ & NR & NR & NR & NR & $>12$ \\
\hline Stumpe et al. [44] & $\mathrm{P} 24, \mathrm{R} 4$ & C15, U13 & NR & $\begin{array}{c}>6 \text { months }(\text { mean } 28 \\
{[6-108 \text { months] })}\end{array}$ & $>6$ \\
\hline Rubello et al. [40] & NR & NR & 4 months to 9.5 years & $>4$ months & $>12$ \\
\hline $\begin{array}{l}\text { Mayer-Wagner et al. } \\
\text { [23] }\end{array}$ & NR & NR & NR & NR & NR \\
\hline Fuster et al. [9] & NR & NR & Median 1.5 years & NR & $>12$ \\
\hline Jung et al. [17] & $\mathrm{P} 24, \mathrm{R} 4$ & NR & 3.4 years $(>3$ months & $>3$ months & $>12$ \\
\hline Basu et al. [2] & NR & NR & NR & $\begin{array}{l}\text { Mean } 3.7 \text { years (FDG-PET), } 6.4 \\
\text { (LS-BMS) }\end{array}$ & $>6$ \\
\hline Kim et al. [18] & NR & NR & Median 3 years ( 2 weeks to 32 years) & NR & $>12$ \\
\hline Granados et al. [12] & NR & NR & Average 78 months & NR & $>12$ \\
\hline
\end{tabular}

$\mathrm{P}=$ primary implant $\mathrm{R}=$ revision; $\mathrm{C}=$ cemented knee prostheses; $\mathrm{U}=$ uncemented knee prostheses; $\mathrm{H}=$ hybrid hip prostheses; $\mathrm{NR}=$ not recorded; FDG-PET = fluorodeoxyglucose-positron emission tomography; LS-BMS = combined leukocyte and bone marrow scintigraphy.

\section{Quantitative Analysis (Meta-analysis)}

For the diagnostic modalities, true-positive, false-positive, true-negative, and false-negative results were derived from a two-by-two contingency table. The interpretation criteria with the highest diagnostic accuracy were selected in case multiple interpretation sets for the same index test were used. When studies reported results for more than one observer, the first readers' findings were included. The statistical heterogeneity of the diagnostic odds ratio (DOR) of each imaging index test across studies was tested using the chi-square test $\left(\mathrm{Q}^{\mathrm{DOR}}\right)$ for independence with $k-1$ degrees of freedom $(k=$ number of studies) [6]. The Spearman rank correlation coefficient $\rho$ value of the DOR was used in case of heterogeneity to measure the correlation between sensitivity and specificity. A $\rho$ of 0.40 or less suggests that the variation between studies may be explained by different cutoff points, or diagnostic thresholds, on a summary receiver operating characteristic curve $[6,25]$. The symmetry of funnel plots was visually interpreted to evaluate possible publication bias.

For all included studies, the test of homogeneity for the DOR indicated no statistical heterogeneity. The studies that evaluated bone scintigraphy (six studies, $\mathrm{n}=216$ knee prostheses), combined bone and leukocyte scintigraphy (four studies, $\mathrm{n}=114$ knee prostheses), leukocyte scintigraphy (six studies, $\mathrm{n}=238$ knee prostheses), 


\section{QUADAS-2 Domain}

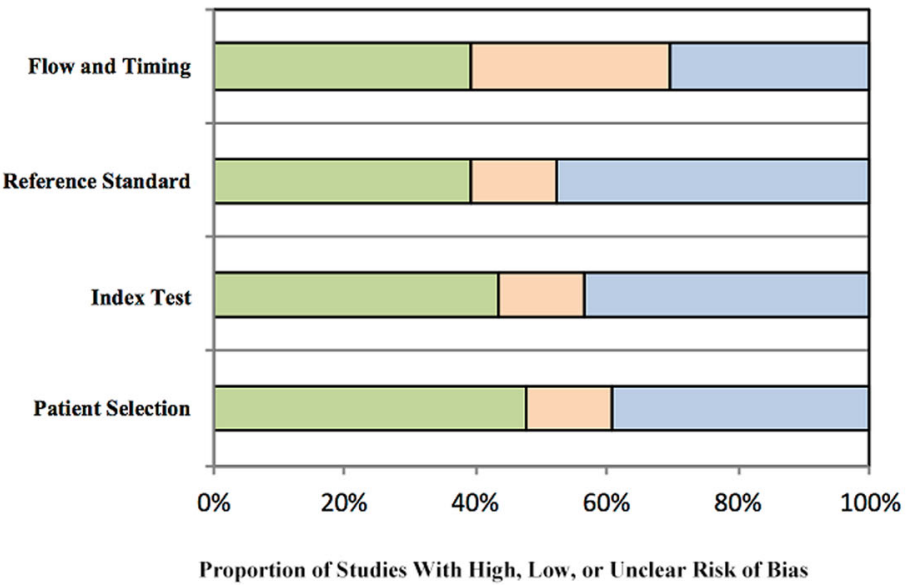

口Low $\square$ High $\square$ Unclear

A

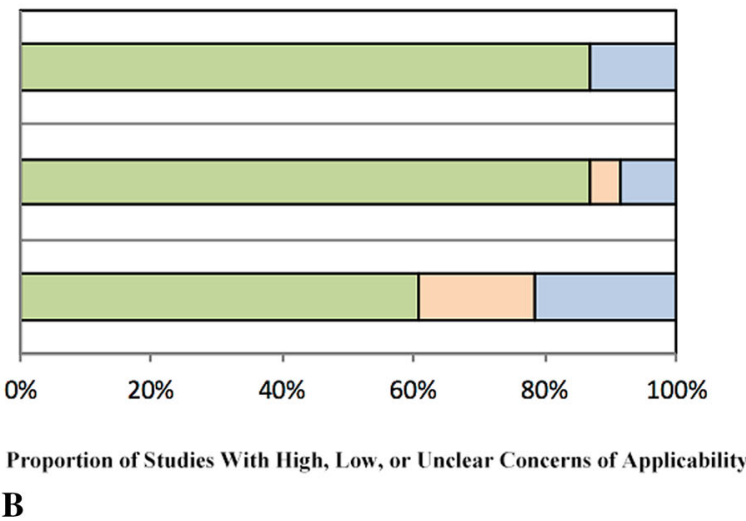

Fig. 2A-B The methodologic quality of the included studies using QUADAS-2 shows the proportions of studies with high, low, or unclear (A) risk of bias and (B) concerns regarding applicability.

Table 3. Comparison of imaging techniques in diagnosing periprosthetic knee infection using the z-test

\begin{tabular}{|c|c|c|c|c|c|c|c|}
\hline \multicolumn{2}{|c|}{ Imaging techniques compared } & \multicolumn{3}{|l|}{ Sensitivity } & \multicolumn{3}{|l|}{ Specificity } \\
\hline Technique 1 & Technique 2 & Technique 1 & Technique 2 & Comparison (p value) & Technique 1 & Technique 2 & Comparison ( $\mathrm{p}$ value) \\
\hline BS & BS-LS & 0.93 & 0.87 & 0.39 & 0.56 & 0.82 & $<0.001$ \\
\hline LS & BS-LS & 0.88 & 0.87 & 0.89 & 0.77 & 0.82 & 0.44 \\
\hline LS & BS & 0.88 & 0.93 & 0.34 & 0.77 & 0.56 & $<0.001$ \\
\hline LS & LS-BMS & 0.88 & 0.80 & 0.24 & 0.77 & 0.93 & $<0.001$ \\
\hline LS-BMS & BS & 0.80 & 0.93 & 0.08 & 0.93 & 0.56 & $<0.001$ \\
\hline LS-BMS & BS-LS & 0.80 & 0.87 & 0.47 & 0.93 & 0.82 & $<0.001$ \\
\hline AGS & $\mathrm{BS}$ & 0.90 & 0.93 & 0.60 & 0.95 & 0.56 & $<0.001$ \\
\hline AGS & BS-LS & 0.90 & 0.87 & 0.70 & 0.95 & 0.82 & 0.01 \\
\hline AGS & LS & 0.90 & 0.88 & 0.72 & 0.95 & 0.77 & $<0.001$ \\
\hline AGS & LS-BMS & 0.90 & 0.80 & 0.21 & 0.95 & 0.93 & 0.47 \\
\hline FDG-PET & BS & 0.70 & 0.93 & 0.06 & 0.84 & 0.56 & $<0.001$ \\
\hline FDG-PET & BS-LS & 0.70 & 0.87 & 0.11 & 0.84 & 0.82 & 0.73 \\
\hline FDG-PET & LS & 0.70 & 0.88 & 0.01 & 0.84 & 0.77 & 0.21 \\
\hline FDG-PET & LS-BMS & 0.70 & 0.80 & 0.30 & 0.84 & 0.93 & $<0.001$ \\
\hline FDG-PET & AGS & 0.70 & 0.90 & 0.02 & 0.84 & 0.95 & 0.02 \\
\hline
\end{tabular}

BS = bone scintigraphy; LS = leukocyte scintigraphy; BMS = bone marrow scintigraphy; AGS = antigranulocyte scintigraphy; FDG$\mathrm{PET}=$ fluorodeoxyglucose-positron emission tomography.

combined leukocyte and bone marrow scintigraphy (seven studies, 144 knee prostheses), antigranulocyte scintigraphy (five studies, $\mathrm{n}=136$ knee prostheses), and FDG-PET (five studies, 179 knee prostheses), the $\mathrm{Q}^{\mathrm{DOR}}$ was 8.09 (5 DOF), 2.90 (3 DOF), 3.52 (5 DOF), 4.69 (6 DOF), 4.70 (4 DOF), and 6.92 (4 DOF), respectively. The funnel plots did not suggest the presence of positive-outcome bias (data not shown).
The sensitivity and specificity were pooled independently and were weighted by the inverse of the variance with use of Meta-DiSc software (Available at: http://www. hrc.es/investigacion/metadisc_en.htm) [55]. The logittransformed sensitivity, specificity, and corresponding $95 \%$ $\mathrm{CI}$ of the index tests were compared with use of z-test statistics. A probability less than 0.05 was considered significant (Table 3). In the comparison of two imaging 
modalities, confidence intervals for two means can overlap and yet the two means can be statistically different from one another at a probability less than $0.05[1,19,36]$. The z-test was used to statistically analyze these differences. A secondary analysis was performed to evaluate possible influence of the methodologic quality on the sensitivity and specificity.

\section{Results}

Bone scintigraphy was less specific (Table 3) than all other modalities tested $(56 \%$; 95\% CI, 0.47-0.64; $\mathrm{p}<0.001)$, and leukocyte scintigraphy (77\%; 95\% CI, 0.69-0.85) was less specific than antigranulocyte scintigraphy (95\%; $95 \%$ CI, 0.88-0.98; $\mathrm{p}<0.001$ ) or combined leukocyte and bone marrow scintigraphy (93\%; $95 \%$ CI, $0.86-0.97$; $\mathrm{p}<0.001)$. FDG-PET (84\%; 95\% CI, 0.76-0.90) was more specific than bone scintigraphy $(56 \%$; $95 \%$ CI, $0.47-$ $0.64 ; \mathrm{p}<0.001)$, and less specific than antigranulocyte scintigraphy $(95 \% ; 95 \% \mathrm{CI}, 0.88-0.98 ; \mathrm{p}=0.02)$ and combined leukocyte and bone marrow scintigraphy (93\%; 95\% CI, 0.86-0.97; p < 0.001).

Leukocyte scintigraphy $(88 \%$; 95\% CI, 0.81-0.93; $\mathrm{p}=0.01)$ and antigranulocyte scintigraphy $(90 \% ; 95 \% \mathrm{CI}$, $0.78-0.96 ; \mathrm{p}=0.02$ ) were more sensitive than FGD-PET (70\%; 95\% CI, 0.56-0.81). However, because of broad overlapping of confidence intervals, no differences in sensitivity were observed among the other modalities, including combined bone scintigraphy (93\%; 95\% CI, 0.85-0.98) or combined leukocyte and bone marrow scintigraphy $(80 \% ; 95 \% \mathrm{CI}, 0.66-0.91 ; \mathrm{p}>0.05$ for all paired comparisons (Table 3).
The secondary analysis, when high risk of bias studies were excluded, showed a higher sensitivity for FDG-PET (93\%; 95\% CI, 0.80-0.98) that was not different than leukocyte scintigraphy $(86 \%$; 95\% CI, 0.76-0.93; $\mathrm{p}=0.39)$ and antigranulocyte scintigraphy $(91 \% ; 95 \%$ CI, 0.78-0.98; 0.18). Combined leukocyte and bone marrow scintigraphy was highly specific (92\%; 95\% CI, 0.84-0.97) and more specific than bone scintigraphy $(55 \%$; $95 \% \mathrm{CI}, 0.45-0.64 ; \mathrm{p} \leq 0.001)$ and leukocyte scintigraphy $(71 \%$; $95 \% \mathrm{CI}, 0.56-0.84$; $\mathrm{p}=0.01)$. However, antigranulocyte scintigraphy $(98 \%$; 95\% CI, 0.92-0.99) was more specific than all other compared imaging modalities; $\mathrm{p}<0.05$ for all paired comparisons.

\section{Discussion}

In the assessment of suspected periprosthetic knee infection, various diagnostic tests including blood tests, synovial fluid microbiologic analyses, and synovial fluid marker tests (such as alpha defensin and synovial fluid CRP), can be used. However, accurate diagnosis of periprosthetic knee infection remains challenging, especially in chronic or low-grade infections, and inconsistent diagnostic accuracies with various tests across studies have been published [10, 11, 22]. Because of that, imaging tests remain important, but studies do not agree on which imaging technique is the most accurate $[11,31]$. Our meta-analysis revealed that in diagnosing periprosthetic knee infection, antigranulocyte scintigraphy and combined leukocyte and bone marrow scintigraphy were highly specific imaging techniques (Fig. 3).

Although the included studies showed statistical homogeneity of data, the reliability of the pooled estimates depends on the methodologic quality of the included

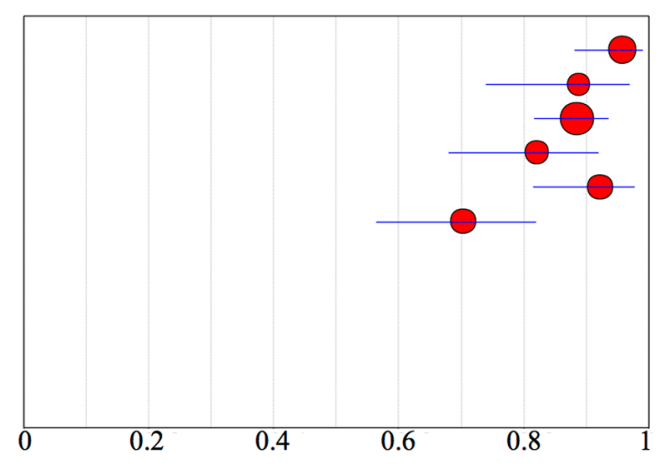

A
Sensitivity

Fig. 3A-B The graphs show the pooled estimates and corresponding 95\% CIs for (A) sensitivity and (B) specificity for all index tests. The size of the circles is proportionate to the number of patients investigated by each technique. $\mathrm{BS}=$ bone scintigraphy; BS/LS = bone and leukocyte scintigraphy; LS = leukocyte scintigraphy; LS/

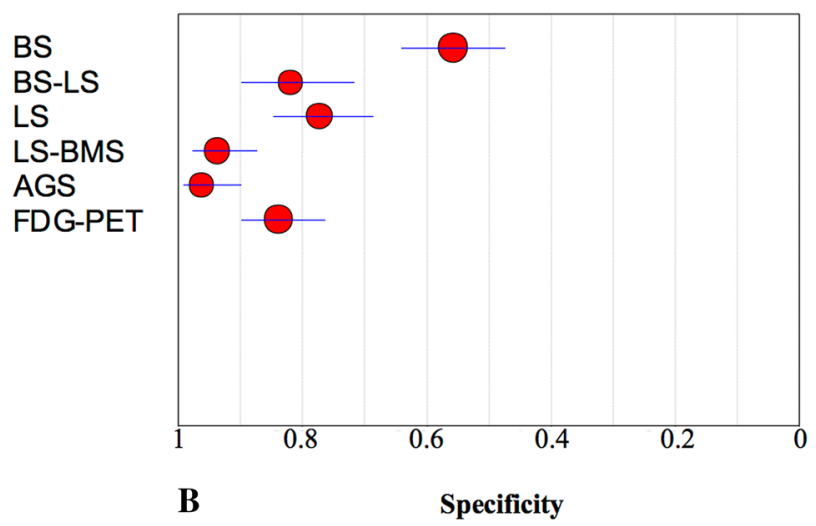

BMS = leukocyte and bone marrow scintigraphy; AGS = antigranulocyte scintigraphy; FDG-PET = fluorodeoxyglucose positron emission tomography. 
studies. There are several limitations of this meta-analysis to consider. Collecting large sample sizes of patients with suspected periprosthetic knee infection is difficult; the total number of infected TKAs included in this meta-analysis was only 288. Subsequently, several studies showed wide confidence intervals, because of small numbers of patients who were evaluated using each diagnostic modality. This means that there may have been differences in sensitivity or specificity between certain modalities that we did not detect. Future comparative studies might help resolve this issue. Studies were not excluded on the basis of methodologic quality. Our secondary analysis, with exclusion of studies that showed a high risk of bias, suggested that FDG-PET might be more sensitive than the primary analysis showed; indeed, it may be comparably sensitive to leukocyte scintigraphy and antigranulocyte scintigraphy. The methodologic quality of the included studies did not substantially influence the sensitivity and specificity of other imaging modalities (data not shown). However, there were important concerns regarding the flow and timing of the included studies. Most of the studies often insufficiently described important variables, including types of implants, use of antibiotics, imaging time after surgery, improvement of imaging techniques, and inter- and intraobserver reliability variance. Consequently, analyses of the effect of these variables on the accuracy of imaging was not possible, but could influence the diagnostic performance of the imaging modalities we studied. In addition, the long period evaluated here (1990 to 2015) saw the introduction of numerous new diagnostic tests (such as alpha defensin and synovial fluid CRP) and new diagnostic standards [4], which might have changed the apparent performance of the imaging modalities we studied and how they might be used in practice. The differentiation between acute or chronic infection influences the decision to evaluate a suspected infection with additional imaging, and should be investigated in additional studies.

Another important limitation of the included studies is the lack of uniform criteria for diagnosis of a periprosthetic infection. We could not restrict inclusion to studies using the Musculoskeletal Infection Society criteria [35] because many of the included studies were performed before the development of these criteria. Although a valid reference standard with microbiologic confirmation was a stringent inclusion criterion in this meta-analysis, there is a risk of false-positive diagnosis of infection, which potentially could decrease specificity. When a diagnosis of no infection was considered, clinical followup sometimes was used to monitor the final diagnosis. Only studies with a clinical followup of at least 6 months were included. For obvious reasons, surgery with microbiologic evaluation could not be performed in all patients (patients believed to be without infection did not always undergo surgery). However, this could result in more false-negative results and potentially decrease the reported specificity when an infection is found after the final diagnosis, especially in the case of a low-grade infection.

Our meta-analysis defined test performance for the various imaging modalities when used in isolation. However, multiple diagnostic tests including aspiration results and laboratory tests can contribute in diagnosing periprosthetic infection, which could influence the diagnostic performance of the evaluated imaging techniques, and generally should improve their performance. During the years, important developments have been described in the diagnosis of periprosthetic infection, including the introduction of alpha defensin and synovial fluid tests $[5,54]$. When the diagnostic evaluation using synovial fluid markers clearly indicates infection, there is little or no need for additional nuclear imaging tests. However, if those tests cannot be obtained or are inconclusive, nuclear imaging can be used in concert with other elements of diagnostic evaluation, including microbiologic analysis and blood testing, to arrive at a more-precise diagnosis than is possible with imaging or laboratory testing alone. Nuclear imaging seldom is used in isolation, and probably should not be used that way [57].

Using bone scintigraphy during the first years after implantation, postoperative tracer (Table 4) uptake can be caused by various factors and therefore lacks the specificity needed to differentiate between aseptic and septic loosening $[10,32]$. Our results (Table 5) confirmed the reputation of high sensitivity and low specificity of this technique [30, 31, 42, 43]. Unfortunately, subgroup analysis of imaging time after implantation could not be performed owing to insufficient data. In clinical practice, imaging often is used to rule out an infection. Bone scintigraphy is widely available and a sensitive tool for evaluation of painful knee prostheses (Fig. 4). However, when confirmation of infection is needed, a positive bone scintigraphy outcome usually leads to a second, more-specific, investigation.

Leukocyte scintigraphy is assumed to be a more specific-imaging modality and has a long history of use in detection of infections [11, 51]. However, our meta-analysis showed that this technique alone may not be the preferred modality for confirming periprosthetic knee infection, given that it has only moderate specificity (77\%) (Table 6). We found that leukocyte scans are very sensitive (88\%) (Fig. 5). However, in contrast to bone scintigraphy, leukocyte scintigraphy is a time-consuming procedure with higher costs and therefore may not be the preferred imaging technique to rule out periprosthetic knee infection. The explanation for the moderate specificity may be that labeled leukocytes (Table 7) not only accumulate in infections, but also physiologically in the bone marrow [33]. To reduce the consequent number of false-positive results, leukocyte scintigraphy can be combined with bone 
Table 4. Study characteristics of bone scintigraphy for detection of periprosthetic knee infection

\begin{tabular}{|c|c|c|c|}
\hline Study & Tracer & Doses & Criteria for infection \\
\hline Palestro et al. [34] & 99mTc-MDP & $740 \mathrm{MBq}$ & $\begin{array}{l}\text { When hyperperfusion and hyperemia around at least one } \\
\text { component of the prosthesis were present on dynamic and blood } \\
\text { pool images and periprosthetic activity of at least Grade } 2 \\
\text { around the same component was present on delayed images }\end{array}$ \\
\hline Nijhof et al. [27] & 99mTc-MDP & $600 \mathrm{MBq}$ & $\begin{array}{l}\text { When there was increased activity in at least two phases (blood } \\
\text { pool and late phase) in the area of interest }\end{array}$ \\
\hline van Acker et al. [50] & 99mTc-MDP & $740 \mathrm{MBq}$ & Any periprosthetic focal uptake in the delayed phase \\
\hline Larikka et al. [20] & 99mTc-HDP & $550 \mathrm{MBq}$ & Uptake in the arterial/flow phase \\
\hline Rubello et al. [40] & 99mTc-MDP & NR & Uptake in the arterial/flow phase \\
\hline Granados et al. [12] & 99mTc-HDP & $925 \mathrm{MBq}$ & Uptake in the arterial/flow phase \\
\hline
\end{tabular}

Diagnostic odds ratio 8.956; heterogeneity chi-square $=8,09(\mathrm{df}=5) \mathrm{p}=0.151$; Inconsistency $\left(\mathrm{I}^{2}\right)=38,2 \% ; 99 \mathrm{mTc}=99 \mathrm{~m}$-technetium; MDP = methylenediphosphonate; HDP = hydroxymethylenediphosphonate.

Table 5. Diagnostic accuracy of bone scintigraphy for detection of periprosthetic knee infection

\begin{tabular}{|c|c|c|c|c|c|c|c|}
\hline \multirow[t]{2}{*}{ Study } & \multirow[t]{2}{*}{ Year } & \multicolumn{2}{|c|}{ Disease } & \multirow[t]{2}{*}{ Sensitivity } & \multirow[t]{2}{*}{$95 \% \mathrm{CI}$} & \multirow[t]{2}{*}{ Specificity } & \multirow[t]{2}{*}{$95 \% \mathrm{CI}$} \\
\hline & & + & - & & & & \\
\hline Palestro et al. [34] & 1991 & 6 & 17 & 0.67 & $0.22-0.96$ & 0.76 & $0.50-0.93$ \\
\hline Nijhof et al. [27] & 1997 & 2 & 5 & 1.00 & $0.12-1.00$ & 0.20 & $0.00-0.72$ \\
\hline van Acker et al. [50] & 2001 & 6 & 15 & 0.83 & $0.36-1.00$ & 0.33 & $0.12-0.62$ \\
\hline Larikka et al. [20] & 2001 & 8 & 22 & 1.00 & $0.57-1.00$ & 0.23 & $0.08-0.54$ \\
\hline Rubello et al. [40] & 2008 & 41 & 37 & 1.00 & $0.89-1.00$ & 0.68 & $0.50-0.82$ \\
\hline Granados et al. [12] & 2015 & 8 & 49 & 1.00 & $0.94-1.00$ & 0.65 & $0.50-0.78$ \\
\hline Total & & 71 & 145 & & & & \\
\hline Pooled estimate & & & & 0.93 & $0.85-0.98$ & 0.56 & $0.47-0.64$ \\
\hline
\end{tabular}

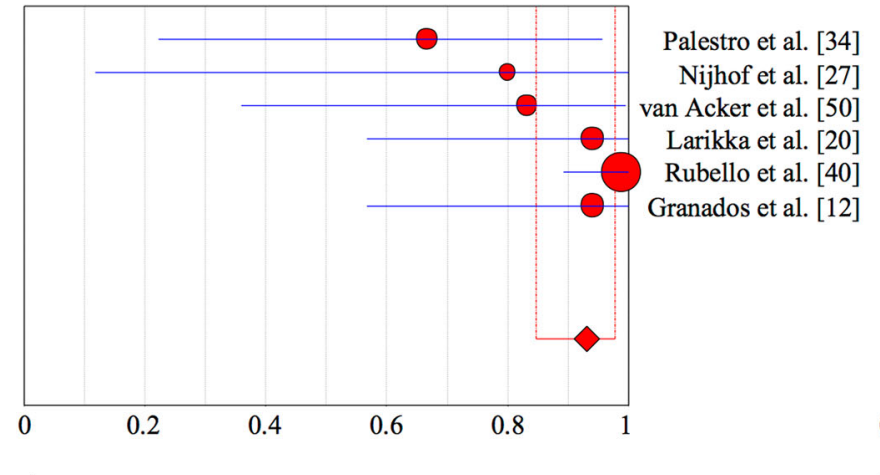

A

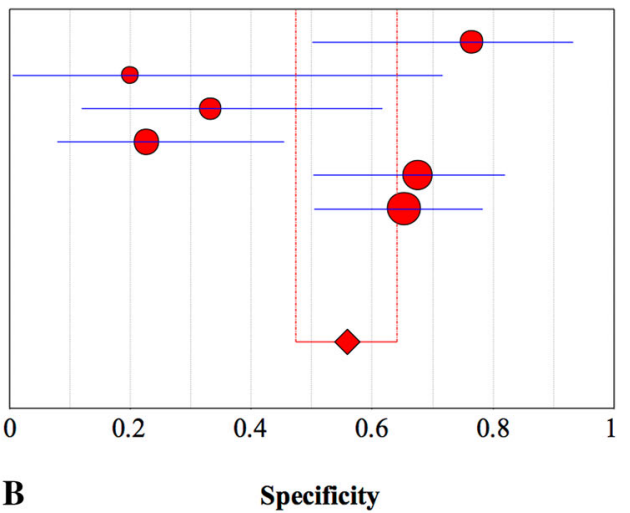

B

Specificity

Fig. 4A-B The pooled (A) sensitivity and (B) specificity of bone scintigraphy in the assessment of periprosthetic knee infection with $95 \%$ CIs are presented.

marrow scintigraphy (Table 8), which has been proposed as the preferred imaging modality for diagnosing prosthetic joint infections $[10,11,22,32]$. The current results for knee prostheses confirmed an increased specificity of $93 \%$ versus $77 \%$ when combining leukocyte with bone marrow scintigraphy (Table 9). Another assessed option to improve specificity (Table 10) was combining leukocyte with bone scintigraphy (Table 11). As expected, specificity did not improve (Fig. 6) [10]. More recently, antigranulocyte scintigraphy was introduced as a less time-consuming alternative for leukocyte scintigraphy with the advantage of in vivo labeling of leukocytes with considerable potential 
Table 6. Diagnostic accuracy of leukocyte scintigraphy for detection of periprosthetic knee infection

\begin{tabular}{|c|c|c|c|c|c|c|c|}
\hline \multirow[t]{2}{*}{ Study } & \multirow[t]{2}{*}{ Year } & \multicolumn{2}{|c|}{ Disease } & \multirow[t]{2}{*}{ Sensitivity } & \multirow[t]{2}{*}{$95 \% \mathrm{CI}$} & \multirow[t]{2}{*}{ Specificity } & \multirow[t]{2}{*}{$95 \% \mathrm{CI}$} \\
\hline & & + & - & & & & \\
\hline Rand \& Brown [38] & 1990 & 18 & 20 & 0.83 & $0.59-0.96$ & 0.85 & $0.62-0.97$ \\
\hline Palestro et al. [34] & 1991 & 9 & 32 & 0.89 & $0.52-1.00$ & 0.75 & $0.57-0.89$ \\
\hline Ooi et al. [28] & 1993 & 3 & 3 & 1.00 & $0.23-1.00$ & 0.67 & $0.09-0.99$ \\
\hline van Acker et al. [50] & 2001 & 5 & 15 & 1.00 & $0.41-1.00$ & 0.53 & $0.27-0.79$ \\
\hline Pelosi et al. [37] & 2004 & 25 & 15 & 0.96 & $0.80-1.00$ & 0.93 & $0.68-1.00$ \\
\hline Kim et al. [18] & 2014 & 63 & 30 & 0.86 & $0.75-0.93$ & 0.80 & $0.61-0.92$ \\
\hline Total & & 123 & 115 & & & & \\
\hline Pooled estimate & & & & 0.88 & $0.81-0.93$ & 0.77 & $0.69-0.85$ \\
\hline
\end{tabular}

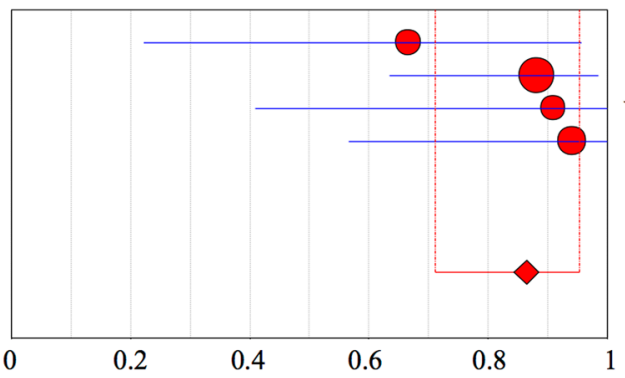

A

Sensitivity

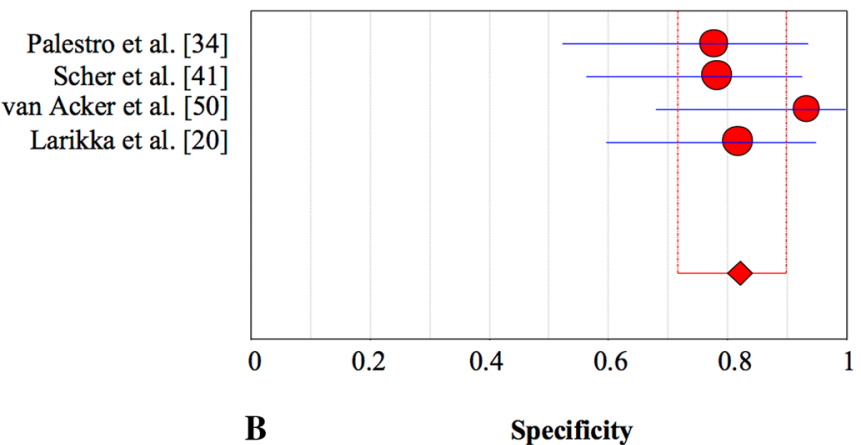

Fig. 5A-B The pooled (A) sensitivity and (B) specificity of leukocyte scintigraphy in the assessment of periprosthetic knee infection with $95 \%$ CIs are shown.

Table 7. Study characteristics of leukocyte scintigraphy for detection of periprosthetic knee infection

\begin{tabular}{|c|c|c|c|}
\hline Study & Tracer & Doses $^{*}$ & Criteria for infection \\
\hline Rand \& Brown [38] & 111 In-Oxine & NR & A focus of moderate to marked increased activity \\
\hline Palestro et al. [34] & 111 In-Oxine & $18.5 \mathrm{MBq}$ & $\begin{array}{l}\text { Periprosthetic activity more intense than that in } \\
\text { corresponding contralateral region }\end{array}$ \\
\hline Ooi et al. [28] & 111 In-Oxine & $7.5-15 \mathrm{MBq}$ & $\begin{array}{l}\text { When there was a focal accumulation at the area of } \\
\text { interest }\end{array}$ \\
\hline van Acker et al. [50] & 99Tc-HMPAO & $185 \mathrm{MBq}$ & Any periprosthetic focal uptake \\
\hline Pelosi et al. [37] & 99Tc-HMPAO & $430-600 \mathrm{MBq}$ & SQ: $\mathrm{K}_{\text {late }}>\mathrm{K}_{\text {early }}$ by at least $10 \%$ \\
\hline Kim et al. [18] & 99Tc-HMPAO & $740-1100 \mathrm{MBq}$ & $\begin{array}{l}\text { Increased uptake in the periprosthetic area or if the } \\
\text { foci in nearby soft tissue had greater activity than } \\
\text { the background soft tissue activity }\end{array}$ \\
\hline
\end{tabular}

\footnotetext{
* Mean doses; SQ = semiquantitative; diagnostic odds ratio 28,143 ; heterogeneity chi-square $=3.52(\mathrm{df}=5)$; $\mathrm{p}=0.620$; inconsistency $\left(\mathrm{I}^{2}\right)=0.0 \% ; \mathrm{K}=$ suspected region of infection/reference region (bone marrow); HMPAO hexamethylpropyleneamine oxime; NR $=$ not reported.
}

in the detection of infection (Table 12) [10,11]. We found antigranulocyte scintigraphy (Table 13) to be more specific than leukocyte scintigraphy and FGD-PET (Table 14). However, its role in the assessment of periprosthetic infection is not yet fully established [10]. An important drawback in clinical practice is that neither antigranulocyte scintigraphy nor leukocyte scintigraphy are widely available and used in clinical practice [10].
FDG-PET is increasingly used and has proposed potential in the diagnosis of PJI, especially regarding hip arthroplasty [10, 39, 51, 58]. Although this technique offers advantages such as time efficiency, increased resolution, and the use of low-dose CT, our results revealed that this technique was less specific in diagnosing periprosthetic knee infection than combined leukocyte and bone marrow scintigraphy and antigranulocyte scintigraphy (Fig. 7). 
Table 8. Study characteristics of combined leukocyte and bone marrow scintigraphy

\begin{tabular}{|c|c|c|c|}
\hline Study & Tracer & Doses & Criteria for infection \\
\hline Palestro et al. [34] & 111In-Oxine/99mTc-SC & $18.5 \mathrm{MBq} / 370 \mathrm{MBq}$ & $\begin{array}{l}\text { If activity was observed on labeled leukocyte images } \\
\text { without corresponding activity on the sulfur colloid } \\
\text { images (incongruent) }\end{array}$ \\
\hline Joseph et al. [16] & 111In-Oxine/99mTc-SC & $500 \mathrm{uCi} / 10 \mathrm{uCi}$ & $\begin{array}{l}\text { Pattern of activity on the indium image that was not } \\
\text { matched on the colloid images }\end{array}$ \\
\hline El Espera et al. [7] & 111In-Oxine/99mTc-SC & $30 \mathrm{MBq} / 185 \mathrm{MBq}$ & $\begin{array}{l}\text { When increased activity was observed on the leukocyte } \\
\text { image at the ROI, without corresponding uptake on the } \\
\text { bone marrow images (incongruent patterns) }\end{array}$ \\
\hline Love et al. [21] & 111In-Oxine/99mTc-SC & $18.5 \mathrm{MBq} / 370 \mathrm{MBq}$ & $\begin{array}{l}\text { Periprosthetic activity on the indium image without } \\
\text { corresponding activity on the marrow scan, regardless of } \\
\text { intensity or location }\end{array}$ \\
\hline Fuster et al. [9] & 99Tc-HMPAO/99mTc-SC & NR & Global imaging analysis; BMS scan inconsistent with LS \\
\hline Jung et al. [17] & 99mTc-HMPAO /99mTc-phytate & $555-740 \mathrm{MBq} / 185 \mathrm{MBq}$ & $\begin{array}{l}\text { Concordant if the distribution of the two radiotracers was } \\
\text { spatially identical, and discordant if activity was } \\
\text { observed in the LS without corresponding activity in the } \\
\text { BMS (discordant was positive for detection of } \\
\text { periprosthetic knee infection) }\end{array}$ \\
\hline Basu et al. [2] & 111In-Oxine/99mTc-SC & $500 \mathrm{uCi} / 555 \mathrm{MBq}$ & $\begin{array}{l}\text { When activity in the periprosthetic region on the leukocyte } \\
\text { image was observed, without corresponding activity on } \\
\text { the bone marrow images }\end{array}$ \\
\hline
\end{tabular}

Diagnostic odds ratio 41,063: heterogeneity chi-square $=4.69(\mathrm{df}=6), \mathrm{p}=0.584$, inconsistency $\left(\mathrm{I}^{2}\right)=0.0 \% ; 99 \mathrm{mTc}-\mathrm{SC}=99 \mathrm{mTc}-\mathrm{sulfur}$ colloid; HMPAO = hexamethylpropyleneamine oxime; ROI = region of interest; LS = leukocyte scintigraphy; BMS = bone marrow scintigraphy; $\mathrm{NR}=$ not reported.

Table 9. Diagnostic accuracy of combined leukocyte and bone marrow scintigraphy for detection of periprosthetic knee infection

\begin{tabular}{|c|c|c|c|c|c|c|c|}
\hline \multirow[t]{2}{*}{ Study } & \multirow[t]{2}{*}{ Year } & \multicolumn{2}{|c|}{ Disease } & \multirow[t]{2}{*}{ Sensitivity } & \multirow[t]{2}{*}{$95 \% \mathrm{CI}$} & \multirow[t]{2}{*}{ Specificity } & \multirow[t]{2}{*}{$95 \% \mathrm{CI}$} \\
\hline & & + & - & & & & \\
\hline Palestro et al. [34] & 1991 & 7 & 12 & 0.86 & $0.42-0.97$ & 1.00 & $0.68-1.00$ \\
\hline Joseph et al. [16] & 2001 & 6 & 16 & 0.67 & $0.22-0.96$ & 1.00 & $0.75-1.00$ \\
\hline El Espera et al. [7] & 2004 & 7 & 21 & 0.71 & $0.29-0.96$ & 0.95 & $0.76-1.00$ \\
\hline Love et al. [21] & 2004 & 11 & 8 & 1.00 & $0.66-1.00$ & 1.00 & $0.57-1.00$ \\
\hline Fuster et al. [9] & 2011 & 6 & 10 & 0.83 & $0.36-1.00$ & 0.90 & $0.56-1.00$ \\
\hline Jung et al. [17] & 2012 & 5 & 6 & 1.00 & $0.41-1.00$ & 0.83 & $0.36-1.00$ \\
\hline Basu et al. [2] & 2014 & 26 & 3 & 0.33 & $0.01-0.91$ & 0.88 & $0.70-0.98$ \\
\hline Total & & 68 & 76 & & & & \\
\hline Pooled estimate & & & & 0.80 & $0.66-0.91$ & 0.93 & $0.86-0.97$ \\
\hline
\end{tabular}

Table 10. Diagnostic accuracy of combined bone and leukocyte scintigraphy for detection of periprosthetic knee infection

\begin{tabular}{|c|c|c|c|c|c|c|c|}
\hline \multirow[t]{2}{*}{ Study } & \multirow[t]{2}{*}{ Year } & \multicolumn{2}{|c|}{ Disease } & \multirow[t]{2}{*}{ Sensitivity } & \multirow[t]{2}{*}{$95 \% \mathrm{CI}$} & \multirow[t]{2}{*}{ Specificity } & \multirow[t]{2}{*}{$95 \% \mathrm{CI}$} \\
\hline & & + & - & & & & \\
\hline Palestro et al. [34] & 1991 & 6 & 18 & 0.67 & $0.23-0.96$ & 0.78 & $0.53-0.94$ \\
\hline Scher et al. [41] & 2000 & 17 & 23 & 0.88 & $0.64-0.99$ & 0.78 & $0.56-0.93$ \\
\hline van Acker et al. [50] & 2001 & 5 & 15 & 1.00 & $0.41-1.00$ & 0.93 & $0.68-1.00$ \\
\hline Larikka et al. [20] & 2001 & 8 & 22 & 1.00 & $0.56-1.00$ & 0.82 & $0.60-0.95$ \\
\hline Total & & 36 & 78 & & & & \\
\hline Pooled estimate & & & & 0.87 & $0.71-0.96$ & 0.82 & $0.72-0.90$ \\
\hline
\end{tabular}




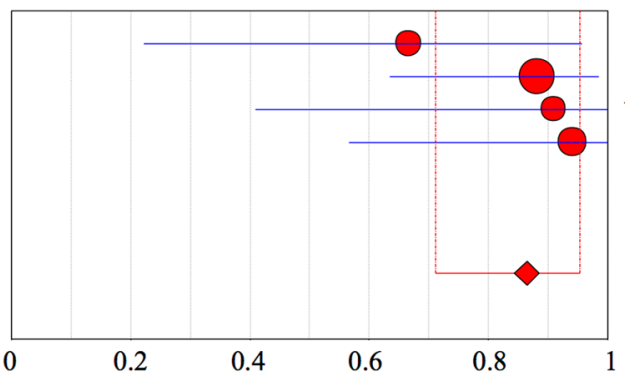

A

Sensitivity

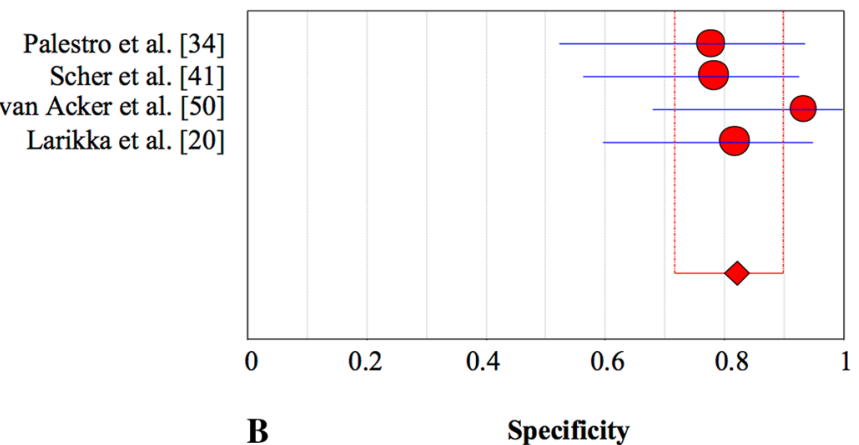

Fig. 6A-B The pooled (A) sensitivity and (B) specificity of combined bone and leukocyte scintigraphy in the assessment of periprosthetic knee infection with $95 \%$ CIs are presented.

Table 11. Study characteristics of combined bone and leukocyte scintigraphy for detection of periprosthetic knee infection

\begin{tabular}{|c|c|c|c|}
\hline Study & Tracer & Doses & Criteria for infection \\
\hline Palestro et al. [34] & 99mTc-MDP/111 In-Oxine & $740 \mathrm{MBq} / 18.5 \mathrm{MBq}$ & $\begin{array}{l}\text { If the distribution of periprosthetic activity on leukocyte } \\
\text { images was spatially similar to the distribution of activity } \\
\text { on bone images but relatively more intense or if the } \\
\text { spatial distribution of the two traces was different } \\
\text { (incongruent) }\end{array}$ \\
\hline Scher et al. [41] & 99mTc-HDP/111 In-Oxine & $925 \mathrm{MBq} / 14.8-18.5 \mathrm{MBq}$ & $\begin{array}{l}\text { When indium scan showed hyperactivity in a different } \\
\text { distribution (incongruency) or a relatively greater } \\
\text { intensity than the activity on the Tc99 scan }\end{array}$ \\
\hline van Acker et al. [50] & 99mTc-MDP/ 9mTc-HMPAO & $740 \mathrm{MBq} / 185 \mathrm{MBq}$ & $\begin{array}{l}\text { Lesions on white blood cell scan that also were found on } \\
\text { the third phase of the bone scan }\end{array}$ \\
\hline Larikka et al. [20] & 99mTc-HDP/99mTc-HMPAO & $550 \mathrm{MBq} / 370 \mathrm{MBq}$ & $\begin{array}{l}\text { When periprosthetic leukocyte uptake intensity was higher } \\
\text { than that of the bone metabolic image in at least one } \\
\text { zone, or if uptake was incongruent }\end{array}$ \\
\hline
\end{tabular}

Diagnostic odds ratio 23,869: heterogeneity chi-square $=2.90(\mathrm{df}=3) ; \mathrm{p}=0.408$; inconsistency $\left(\mathrm{I}^{2}\right)=0.0 \% ;$ Tc99 $\mathrm{m}=99 \mathrm{~m}$-technetium; MDP $=$ methylenediphosphonate; HDP = hydroxymethylenediphosphonate; 99Tc-HMPAO = hexamethylpropyleneamine oxime.

Table 12. Study characteristics of antigranulocyte scintigraphy for detection of periprosthetic knee infection

\begin{tabular}{|c|c|c|c|}
\hline Study & Antibody type & $99 \mathrm{mTc}$ doses & Criteria for infection \\
\hline Ivancevic et al. [14] & Sulesomab $^{2}$ & $<1.1 \mathrm{GBq}$ & $\begin{array}{l}\text { Uptake higher than that in the bone marrow of the } \\
\text { contralateral iliac crest }\end{array}$ \\
\hline von Rothenburg et al. [52] & Sulesomab ${ }^{2}$ & $15-25 \mathrm{mCi}$ & $\begin{array}{l}\text { When there was abnormal uptake greater than could be } \\
\text { expected from a blood pool effect (Q) }\end{array}$ \\
\hline Iyengar \& Vinjamuri [15] & Sulesomab $^{2}$ & $650 \mathrm{MBq}$ & $\begin{array}{l}\text { Uptake in the ROI was greater than the uptake in the } \\
\text { surrounding normal tissue or the contralateral side }\end{array}$ \\
\hline Stumpe et al. [44] & Besilesomab $^{1}$ & NR & $\begin{array}{l}\text { If the intensity of accumulation around the BPI exceeded } \\
\text { physiologic bone marrow uptake or if the intensity of } \\
\text { radionuclide uptake increased from 4-24 hours }\end{array}$ \\
\hline Rubello et al. [40] & Sulesomab $^{2}$ & $740 \mathrm{MBq}$ & $\begin{array}{l}\text { Dual interpretation (early and delayed): if on the delayed } \\
\text { leukoscan imaging, the uptake increased by one step or } \\
\text { more in comparison to the baseline (early leukoscan) }\end{array}$ \\
\hline
\end{tabular}

Diagnostic odds ratio 84,598, heterogeneity chi-square $=4.70(\mathrm{df}=4), \mathrm{p}=0.320$, inconsistency $\left(\mathrm{I}^{2}\right)=14.9 \%$; $\mathrm{SQ}=$ semiquantitative; $\mathrm{Q}=$ qualitative; ROI = region of interest; BPI = bone-prosthesis interface; ${ }^{1} 99 \mathrm{mTc}$-anti-NCA $95 ;{ }^{2} 99 \mathrm{mTc}$-anti-NCA90.

Some investigations concluded that uptake patterns rather than intensity in the bone-prosthesis interface are specific in diagnosing periprosthetic infection (Table 15) $[2,56]$. In particular, the sensitivity of $70 \%$ is only moderate (Fig. 8 ) and was lower than the sensitivity of leukocyte or antigranulocyte scintigraphy (Fig. 9). However, our secondary analysis revealed that FDG-PET was highly sensitive (93\%) when low-quality studies were excluded [21, 23], 
Table 13. Diagnostic accuracy of antigranulocyte scintigraphy for detection of periprosthetic knee infection

\begin{tabular}{|c|c|c|c|c|c|c|c|}
\hline \multirow[t]{2}{*}{ Study } & \multirow[t]{2}{*}{ Year } & \multicolumn{2}{|c|}{ Disease } & \multirow[t]{2}{*}{ Sensitivity } & \multirow[t]{2}{*}{$95 \% \mathrm{CI}$} & \multirow[t]{2}{*}{ Specificity } & \multirow[t]{2}{*}{$95 \% \mathrm{CI}$} \\
\hline & & + & - & & & & \\
\hline Ivancevic et al. [14] & 2002 & 2 & 3 & 1.00 & $0.12-1.00$ & 0.67 & $0.10-0.99$ \\
\hline von Rothenburg et al. [52] & 2004 & 4 & 8 & 1.00 & $0.33-1.00$ & 1.00 & $0.57-1.00$ \\
\hline Iyengar \& Vinjamuri [15] & 2005 & 2 & 11 & 1.00 & $0.12-1.00$ & 0.82 & $0.48-0.98$ \\
\hline Stumpe et al. [44] & 2006 & 3 & 25 & 0.67 & $0.10-0.99$ & 1.00 & $0.83-1.00$ \\
\hline Rubello et al. [40] & 2008 & 41 & 37 & 0.93 & $0.80-0.99$ & 1.00 & $0.88-1.00$ \\
\hline Total & & 52 & 84 & & & & \\
\hline Pooled estimate & & & & 0.90 & $0.78-0.96$ & 0.95 & $0.88-0.98$ \\
\hline
\end{tabular}

Table 14. Diagnostic accuracy of fluorodeoxyglucose-positron emission tomography for detection of periprosthetic hip infection

\begin{tabular}{|c|c|c|c|c|c|c|c|}
\hline \multirow[t]{2}{*}{ Study } & \multirow[t]{2}{*}{ Year } & \multicolumn{2}{|c|}{ Disease } & \multirow[t]{2}{*}{ Sensitivity } & \multirow[t]{2}{*}{$95 \% \mathrm{CI}$} & \multirow[t]{2}{*}{ Specificity } & \multirow[t]{2}{*}{$95 \% \mathrm{CI}$} \\
\hline & & + & - & & & & \\
\hline van Acker et al. [50] & 2001 & 6 & 15 & 1.00 & $0.47-1.00$ & 0.73 & $0.45-0.92$ \\
\hline Zhuang et al. [56] & 2001 & 11 & 25 & 0.91 & $0.59-1.00$ & 0.72 & $0.51-0.88$ \\
\hline Love et al. [21] & 2004 & 11 & 8 & 0.27 & $0.06-0.61$ & 1.00 & $0.57-1.00$ \\
\hline Mayer-Wagner et al. [23] & 2010 & 7 & 9 & 0.14 & $0.00-0.58$ & 0.89 & $0.52-1.00$ \\
\hline Basu et al. [2] & 2014 & 19 & 68 & 0.95 & $0.74-1.00$ & 0.88 & $0.78-0.95$ \\
\hline Total & & 54 & 125 & & & & \\
\hline Pooled estimate & & & & 0.70 & $0.56-0.81$ & 0.84 & $0.76-0.90$ \\
\hline
\end{tabular}

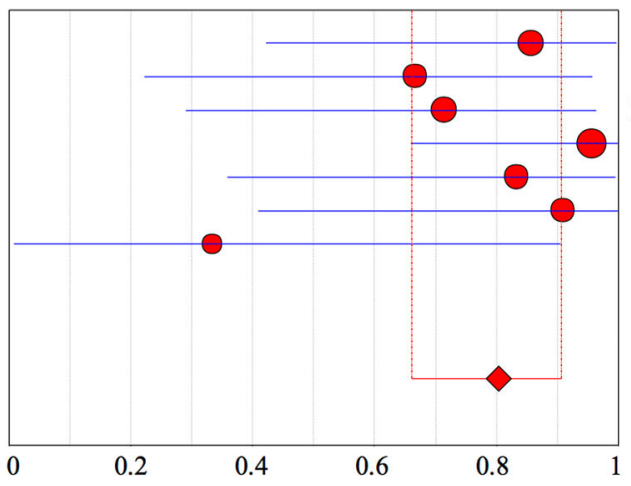

A

Sensitivity
Palestro et al. [34]

Joseph et al. [16]

E1 Espera et al. [7]

Love et al. [21]

Fuster et al. [9]

Jung et al. [17]

Basu et al. [2]

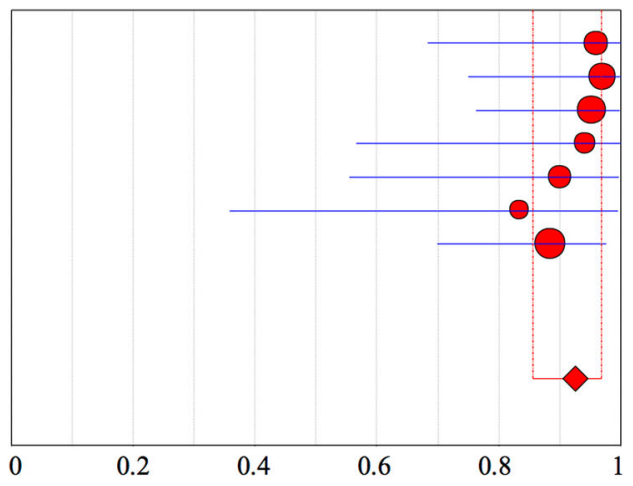

B

Specificity

Fig. 7A-B The pooled (A) sensitivity and (B) specificity of combined leukocyte and bone marrow scintigraphy in the assessment of periprosthetic knee infection with $95 \%$ CIs are presented.

Table 15. Study characteristics of fluorodeoxyglucose positron emission tomography for detection of periprosthetic hip infection

\begin{tabular}{|c|c|c|c|}
\hline Study & Tracer & Doses & Criteria for infection \\
\hline van Acker et al. [50] & 18F-FDG & $3.7 * \mathrm{Kg} / 8 \mathrm{MBq}$ & Focal FDG uptake at the BPI \\
\hline Zhuang et al. [56] & 18F-FDG & 4.22-4.56 MBq/kg & $\begin{array}{l}\text { When an area of increased uptake was detected in the BPI, } \\
\text { compared with adjacent soft tissue }\end{array}$ \\
\hline Love et al. [21] & 18F-FDG & $150-220 \mathrm{MBq}$ & $\begin{array}{l}\text { Semiquantitative analysis of bone-prosthesis-interface } \\
\text { (target-background ratio) }\end{array}$ \\
\hline Mayer-Wagner et al. [23] & 18F-FDG & $180 \mathrm{MBq}$ & $\begin{array}{l}\text { Increased uptake at the distal BPI of the femoral shield and/ } \\
\text { or of the stem of the tibial prosthesis }\end{array}$ \\
\hline Basu et al. [2] & 18F-FDG & $0.14 \mathrm{mCi} / \mathrm{kg}$ & Only uptake in the BPI \\
\hline
\end{tabular}

Diagnostic odds ratio 19,083: heterogeneity chi-square $=6.92 \quad(\mathrm{df}=4), \mathrm{p}=0.140$, inconsistency $\left(\mathrm{I}^{2}\right)=42.2 \%$; $18 \mathrm{~F}-\mathrm{FDG}=$ fluorodeoxyglucose (18F-FDG); BPI = bone-prosthesis interface. 


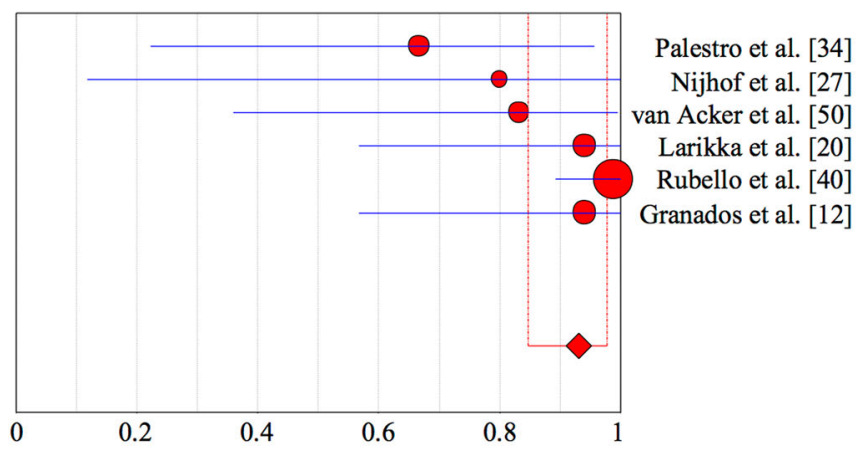

A

Sensitivity

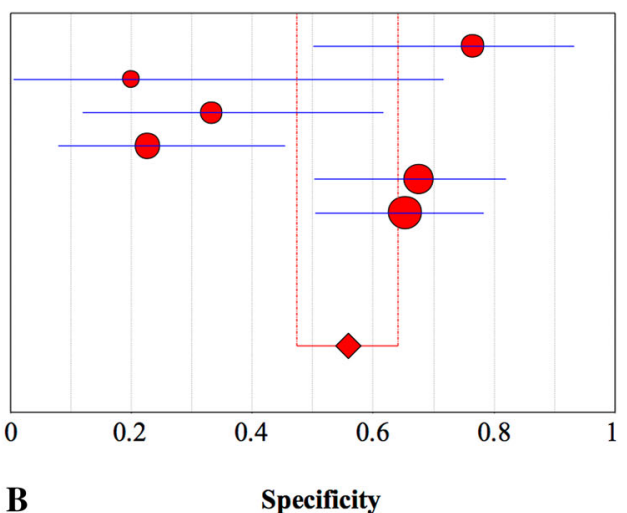

Specificity

Fig. 8A-B The pooled (A) sensitivity and (B) specificity of FDG-PET in the assessment of periprosthetic knee infection with $95 \%$ CIs are shown. FDG-PET = fluorodeoxyglucose-positron emission tomography.

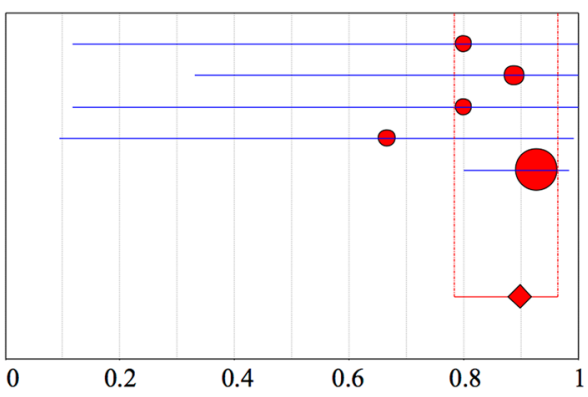

$\mathbf{A}$

Sensitivity

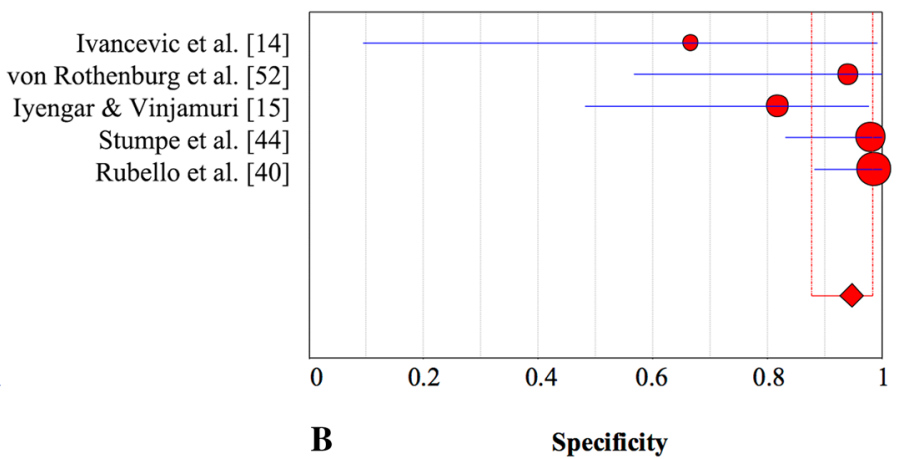

Fig. 9A-B The pooled (A) sensitivity and (B) specificity of antigranulocyte scintigraphy in the assessment of periprosthetic knee infection with 95\% CIs are shown.

which is not less sensitive than the other imaging techniques evaluated. This should be considered further in well-designed studies. The specificity was not higher than that of combined leukocyte and bone marrow scintigraphy and antigranulocyte scintigraphy. An important drawback of FDG-PET is the high cost compared with other imaging modalities. Therefore, FDG-PET may not be the preferred imaging modality in the evaluation of a suspected infected knee prosthesis.

This meta-analysis revealed that, based on current evidence, antigranulocyte scintigraphy and combined leukocyte and bone marrow scintigraphy were highly specific in confirming periprosthetic knee infection. However, the time-consuming procedures and limited availability are important drawbacks of these techniques. Bone scintigraphy was highly sensitive but lacks the specificity in differentiating between various conditions of painful knee prostheses. FDG-PET may not be the preferred imaging modality because it is more expensive and not more effective in confirming infected knee prostheses. In practice, other tests should be used in concert with the evaluated imaging modalities to arrive at more-sensitive and specific diagnostic decisions than are possible with imaging or laboratory testing alone. Future, larger prospective studies should assess the utility of imaging in the diagnostic algorithm of a suspected periprosthetic knee infection, providing more data to evaluate important variables, including the differentiation between acute and chronic infections.

Acknowledgments We thank Chantal den Haan BSc (medical informatics specialist, Onze Lieve Vrouwe Gasthuis Hospital, Amsterdam), for her contribution in constructing a search strategy for this systematic review and meta-analysis.

Open Access This article is distributed under the terms of the Creative Commons Attribution 4.0 International License (http:// creativecommons.org/licenses/by/4.0/), which permits unrestricted use, distribution, and reproduction in any medium, provided you give appropriate credit to the original author(s) and the source, provide a link to the Creative Commons license, and indicate if changes were made.

\section{References}

1. Austin PC, Hux JE. A brief note on overlapping confidence intervals. J Vasc Surg. 2002;36:194-195.

2. Basu S, Kwee TC, Saboury B, Garino JP, Nelson CL, Zhuang H, Parsons M, Chen W, Kumar R, Salavati A, Werner TJ, Alavi A. 
FDG PET for diagnosing infection in hip and knee prostheses: prospective study in 221 prostheses and subgroup comparison with combined (111)In-labeled leukocyte/(99 m)Tc-sulfur colloid bone marrow imaging in 88 prostheses. Clin Nucl Med. 2014;39:609-615.

3. Blom AW, Brown J, Taylor AH, Pattison G, Whitehouse S, Bannister GC. Infection after total knee arthroplasty. J Bone Joint Surg Br. 2004;86:688-691.

4. Cats-Baril W, Gehrke T, Huff K, Kendoff D, Maltenfort M, Parvizi J. International consensus on periprosthetic joint infection: description of the consensus process. Clin Orthop Relat Res. 2013;471:4065-4075.

5. Deirmengian C, Kardos K, Kilmartin P, Cameron A, Schiller K, Booth RE Jr, Parvizi J. The alpha-defensin test for periprosthetic joint infection outperforms the leukocyte esterase test strip. Clin Orthop Relat Res. 2015;473:198-203.

6. Deville WL, Buntinx F, Bouter LM, Montori VM, de Vet HC, van der Windt DA, Bezemer PD. Conducting systematic reviews of diagnostic studies: didactic guidelines. BMC Med Res Methodol. 2002;2:9.

7. El Espera I, Blondet C, Moullart V, Saidi L, Havet E, Mertl P, Canarelli B, Schmit JL, Meyer ME. The usefulness of $99 \mathrm{mTc}$ sulfur colloid bone marrow scintigraphy combined with $111 \mathrm{In}$ leucocyte scintigraphy in prosthetic joint infection. Nucl Med Commun. 2004;25:171-175.

8. Feldman DS, Lonner JH, Desai P, Zuckerman JD. The role of intraoperative frozen sections in revision total joint arthroplasty. $J$ Bone Joint Surg Am. 1995;77:1807-1813.

9. Fuster D, Soriano A, Garcia S, Piera C, Suades J, Rodriguez D, Martinez JC, Mensa J, Campos F, Pons F. Usefulness of 99 mTcciprofloxacin scintigraphy in the diagnosis of prosthetic joint infections. Nucl Med Commun. 2011;32:44-51.

10. Gemmel F, Van den Wyngaert H, Love C, Welling MM, Gemmel $\mathrm{P}$, Palestro CJ. Prosthetic joint infections: radionuclide state-ofthe-art imaging. Eur J Nucl Med Mol Imaging. 2012;39:892-909.

11. Glaudemans AW, Galli F, Pacilio M, Signore A. Leukocyte and bacteria imaging in prosthetic joint infection. Eur Cell Mater. 2013;25:61-77.

12. Granados U, Fuster D, Soriano A, Garcia S, Bori G, Martinez JC, Mayoral M, Perlaza P, Tomas X, Pons F. [Screening with angiographic images prior to $(99 \mathrm{~m}) \mathrm{Tc}-\mathrm{HMPAO}$ labelled leukocyte scintigraphy in the diagnosis of periprosthetic infection][in Spanish]. Rev Esp Med Nucl Imagen Mol. 2015;34:219-224.

13. Hughes PW, Salvati EA, Wilson PD Jr, Blumenfeld EL. Treatment of subacute sepsis of the hip by antibiotics and joint replacement: criteria for diagnosis with evaluation of twenty-six cases. Clin Orthop Relat Res. 1979;141:143-157.

14. Ivancevic V, Perka C, Hasart O, Sandrock D, Munz DL. Imaging of low-grade bone infection with a technetium- $99 \mathrm{~m}$ labelled monoclonal anti-NCA-90 Fab' fragment in patients with previous joint surgery. Eur J Nucl Med Mol Imaging. 2002;29:547-551.

15. Iyengar KP, Vinjamuri S. Role of $99 \mathrm{mTc}$ Sulesomab in the diagnosis of prosthetic joint infections. Nucl Med Commun. 2005;26:489-496.

16. Joseph TN, Mujtaba M, Chen AL, Maurer SL, Zuckerman JD, Maldjian C, Di Cesare PE. Efficacy of combined technetium$99 \mathrm{~m}$ sulfur colloid/indium-111 leukocyte scans to detect infected total hip and knee arthroplasties. J Arthroplasty. 2001;16:753758.

17. Jung KP, Park JS, Lee AY, Choi SJ, Lee SM, Bae SK. The clinical usefulness of (99 m)Tc HMPAO leukocyte/(99 m)Tc phytate bone marrow scintigraphy for diagnosis of prosthetic knee infection: a preliminary study. Nucl Med Mol Imaging. 2012;46:247-253.
18. Kim HO, Na SJ, Oh SJ, Jung BS, Lee SH, Chang JS, Bin SI, Ryu JS. Usefulness of adding SPECT/CT to $99 \mathrm{mTc}$-hexamethylpropylene amine oxime (HMPAO)-labeled leukocyte imaging for diagnosing prosthetic joint infections. J Comput Assist Tomogr. 2014;38:313-319.

19. Knol MJ, Pestman WR, Grobbee DE. The (mis)use of overlap of confidence intervals to assess effect modification. Eur J Epidemiol. 2011;26:253-254.

20. Larikka MJ, Ahonen AK, Junila JA, Niemela O, Hamalainen MM, Syrjala HP. Improved method for detecting knee replacement infections based on extended combined $99 \mathrm{mTc}$-white blood cell/bone imaging. Nucl Med Commun. 2001;22:11451150.

21. Love C, Marwin SE, Tomas MB, Krauss ES, Tronco GG, Bhargava KK, Nichols KJ, Palestro CJ. Diagnosing infection in the failed joint replacement: a comparison of coincidence detection 18F-FDG and 111In-labeled leukocyte/99mTc-sulfur colloid marrow imaging. J Nucl Med. 2004;45:1864-1871.

22. Love C, Tomas MB, Marwin SE, Pugliese PV, Palestro CJ. Role of nuclear medicine in diagnosis of the infected joint replacement. Radiographics. 2001;21:1229-1238.

23. Mayer-Wagner S, Mayer W, Maegerlein S, Linke R, Jansson V, Muller PE. Use of 18F-FDG-PET in the diagnosis of endoprosthetic loosening of knee and hip implants. Arch Orthop Trauma Surg. 2010;130:1231-1238.

24. Moher D, Liberati A, Tetzlaff J, Altman DG; PRISMA Group. Preferred reporting items for systematic reviews and meta-analyses: the PRISMA statement. PLoS Med. 2009;6:e1000097.

25. Moses LE, Shapiro D, Littenberg B. Combining independent studies of a diagnostic test into a summary ROC curve: dataanalytic approaches and some additional considerations. Stat Med. 1993;12:1293-1316.

26. Namba RS, Inacio MC, Paxton EW. Risk factors associated with deep surgical site infections after primary total knee arthroplasty: an analysis of 56,216 knees. J Bone Joint Surg Am. 2013;95:775782.

27. Nijhof MW, Oyen WJ, van Kampen A, Claessens RA, van der Meer JW, Corstens FH. Evaluation of infections of the locomotor system with indium-111-labeled human IgG scintigraphy. $J$ Nucl Med. 1997;38:1300-1305.

28. Ooi GC, Belton I, Finlay D. Comparison of technetium 99m nanocolloid and indium 111 leucocytes in the diagnosis of orthopaedic infections. Br J Radiol. 1993;66:1025-1030.

29. Osmon DR, Berbari EF, Berendt AR, Lew D, Zimmerli W, Steckelberg JM, Rao N, Hanssen A, Wilson WR; Infectious Diseases Society of America. Diagnosis and management of prosthetic joint infection: clinical practice guidelines by the Infectious Diseases Society of America. Clin Infect.Dis. 2013;56:e1-e25.

30. Ouyang Z, Li H, Liu X, Zhai Z, Li X. Prosthesis infection: diagnosis after total joint arthroplasty with three-phase bone scintigraphy. Ann Nucl Med. 2014;28:994-1003.

31. Palestro CJ. Nuclear medicine, the painful prosthetic joint, and orthopedic infection. J Nucl Med. 2003;44:927-929.

32. Palestro CJ. Nuclear medicine and the failed joint replacement: past, present, and future. World J Radiol. 2014;6:446-458.

33. Palestro CJ, Love C, Tronco GG, Tomas MB, Rini JN. Combined labeled leukocyte and technetium $99 \mathrm{~m}$ sulfur colloid bone marrow imaging for diagnosing musculoskeletal infection. Radiographics. 2006;26:859-870.

34. Palestro CJ, Swyer AJ, Kim CK, Goldsmith SJ. Infected knee prosthesis: diagnosis with In-111 leukocyte, Tc-99m sulfur colloid, and Tc-99m MDP imaging. Radiology. 1991;179:645-648.

35. Parvizi J, Zmistowski B, Berbari EF, Bauer TW, Springer BD, Della Valle CJ, Garvin KL, Mont MA, Wongworawat MD, Zalavras CG. New definition for periprosthetic joint infection: 
from the Workgroup of the Musculoskeletal Infection Society. Clin Orthop Relat Res. 2011;469:2992-2994.

36. Payton ME, Greenstone MH, Schenker N. Overlapping confidence intervals or standard error intervals: what do they mean in terms of statistical significance? J Insect Sci. 2003;3:34.

37. Pelosi E, Baiocco C, Pennone M, Migliaretti G, Varetto T, Maiello A, Bello M, Bisi G. 99mTc-HMPAO-leukocyte scintigraphy in patients with symptomatic total hip or knee arthroplasty: improved diagnostic accuracy by means of semiquantitative evaluation. J Nucl Med. 2004;45:438-444.

38. Rand JA, Brown ML. The value of indium 111 leukocyte scanning in the evaluation of painful or infected total knee arthroplasties. Clin Orthop Relat Res. 1990;259:179-182.

39. Reinartz P. FDG-PET in patients with painful hip and knee arthroplasty: technical breakthrough or just more of the same. $Q J$ Nucl Med Mol Imaging. 2009;53:41-50.

40. Rubello D, Rampin L, Banti E, Massaro A, Cittadin S, Cattelan AM, Al-Nahhas A. Diagnosis of infected total knee arthroplasty with anti-granulocyte scintigraphy: the importance of a dual-time acquisition protocol. Nucl Med Commun. 2008;29:331-335.

41. Scher DM, Pak K, Lonner JH, Finkel JE, Zuckerman JD, Di Cesare PE. The predictive value of indium-111 leukocyte scans in the diagnosis of infected total hip, knee, or resection arthroplasties. J Arthroplasty. 2000;15:295-300.

42. Segura AB, Munoz A, Brulles YR, Hernandez Hermoso JA, Diaz MC, Bajen Lazaro MT, Martin-Comin J. What is the role of bone scintigraphy in the diagnosis of infected joint prostheses? Nucl Med Commun. 2004;25:527-532.

43. Simonsen L, Buhl A, Oersnes T, Duus B. White blood cell scintigraphy for differentiation of infection and aseptic loosening: a retrospective study of 76 painful hip prostheses. Acta Orthop. 2007;78:640-647.

44. Stumpe KD, Romero J, Ziegler O, Kamel EM, von Schulthess GK, Strobel K, Hodler J. The value of FDG-PET in patients with painful total knee arthroplasty. Eur J Nucl Med Mol Imaging. 2006;33:1218-1225.

45. Temmerman OP, Raijmakers PG, Berkhof J, Hoekstra OS, Teule GJ, Heyligers IC. Accuracy of diagnostic imaging techniques in the diagnosis of aseptic loosening of the femoral component of a hip prosthesis: a meta-analysis. $J$ Bone Joint Surg Br. 2005;87:781-785.

46. Temmerman OP, Raijmakers PG, David EF, Pijpers R, Molenaar MA, Hoekstra OS, Berkhof J, Manoliu RA, Teule GJ, Heyligers IC. A comparison of radiographic and scintigraphic techniques to assess aseptic loosening of the acetabular component in a total hip replacement. J Bone Joint Surg Am. 2004;86:2456-2463.

47. Temmerman OP, Raijmakers PG, Deville WL, Berkhof J, Hooft L, Heyligers IC. The use of plain radiography, subtraction arthrography, nuclear arthrography, and bone scintigraphy in the diagnosis of a loose acetabular component of a total hip prosthesis: a systematic review. J Arthroplasty. 2007;22:818-827.

48. Termaat MF, Raijmakers PG, Scholten HJ, Bakker FC, Patka P, Haarman HJ. The accuracy of diagnostic imaging for the assessment of chronic osteomyelitis: a systematic review and meta-analysis. J Bone Joint Surg Am. 2005;87:2464-2471.

49. Toms AD, Davidson D, Masri BA, Duncan CP. The management of peri-prosthetic infection in total joint arthroplasty. J Bone Joint Surg Br. 2006;88:149-155.

50. Van Acker F, Nuyts J, Maes A, Vanquickenborne B, Stuyck J, Bellemans J, Vleugels S, Bormans G, Mortelmans L. FDG-PET, 99mtc-HMPAO white blood cell SPET and bone scintigraphy in the evaluation of painful total knee arthroplasties. Eur J Nucl Med. 2001;28:1496-1504.

51. Verberne SJ, Raijmakers PG, Temmerman OP. The accuracy of imaging techniques in the assessment of periprosthetic hip infection: a systematic review and meta-analysis. J Bone Joint Surg Am. 2016;98:1638-1645.

52. von Rothenburg T, Schoellhammer M, Schaffstein J, Koester O, Schmid G. Imaging of infected total arthroplasty with Tc-99mlabeled antigranulocyte antibody Fab'fragments. Clin Nucl Med. 2004;29:548-551.

53. Whiting PF, Rutjes AW, Westwood ME, Mallett S, Deeks JJ, Reitsma JB, Leeflang MM, Sterne JA, Bossuyt PM; QUADAS-2 Group. QUADAS-2: a revised tool for the quality assessment of diagnostic accuracy studies. Ann Intern Med. 2011;155:529-536.

54. Wyatt MC, Beswick AD, Kunutsor SK, Wilson MJ, Whitehouse MR, Blom AW. The alpha-defensin immunoassay and leukocyte esterase colorimetric strip test for the diagnosis of periprosthetic infection: a systematic review and meta-analysis. J Bone Joint Surg Am. 2016;98:992-1000.

55. Zamora J, Abraira V, Muriel A, Khan K, Coomarasamy A. MetaDiSc: a software for meta-analysis of test accuracy data. BMC Med Res Methodol. 2006;6:31.

56. Zhuang H, Duarte PS, Pourdehnad M, Maes A, Van Acker F, Shnier D, Garino JP, Fitzgerald RH, Alavi A. The promising role of 18F-FDG PET in detecting infected lower limb prosthesis implants. J Nucl Med. 2001;42:44-48.

57. Zmistowski B, Della Valle C, Bauer TW, Malizos KN, Alavi A, Bedair H, Booth RE, Choong P, Deirmengian C, Ehrlich GD, Gambir A, Huang R, Kissin Y, Kobayashi H, Kobayashi N, Krenn V, Drago L, Marston SB, Meermans G, Perez J, Ploegmakers JJ, Rosenberg A, Simpendorfer C, Thomas P, Tohtz S, Villafuerte JA, Wahl P, Wagenaar FC, Witzo E. Diagnosis of periprosthetic joint infection. J Arthroplasty. 2014;29(2 suppl):77-83.

58. Zoccali C, Teori G, Salducca N. The role of FDG-PET in distinguishing between septic and aseptic loosening in hip prosthesis: a review of literature. Int Orthop. 2009;33:1-5. 